\title{
海外の法面緑化状沉について(II)
}

\author{
一アメリ カ \\ 小橋 澄 治*.森 本幸 裕**
}

アメリカ合衆国のうち, 特に印象深かった Blue Ridge Park Way, Vail pass, ロスアンジェルス周辺部につい てのベる。

\section{Blue Ridge Parkway}

\section{1 その成立, 概要}

南アパラシアン山脈を縦断する立派な観光道路があ る。それは Shenandoah 国立公園と Great Smoky Mountain 国立公園を結ぶものであり, Shenandoah 国 立公園を縦断する Skyline drive (Virginia 州 Front Royal より Waynesboro まで約 100 マイル)とそれに接 続して Great Smoky mts. 国立公園を結ぶ Blue Ridge Parkway (Virginia 州 Waynesboro より North Caroilna 州 cherokee まで約 470 マイル)よりなる。

この道路は Blue Ridge と呼ばれる山脈のほほ山の背 近くを縦断しており，2,000 3, 000 feet の海抜高の部 分が多く, 5, 000 feet を越える個所もある。比較的なだ らかな山体であり, 地質は古生層変成岩, 古い花南岩( そ れも先カンブリア紀の非常に古いものを含えでいる) で ある。

Blue Ridge parkway の統計によれば 1981 年には年 間約 1,700 万人の観光客が訪れるという非常に利用度の 高い Parkway である。parkway というのは USA の National Park Service によって管理運営される道路で あり, USA で 4 路線ある内の一つである。

この付近の低地は 1800 年頃には農業が行われおり, 人為的影響はしだいに山地に及び†，20世紀に入ると森 林の伐採, 農地化, 牧場化がはげしくなり, 原生林はほ とえど姿を消した。それと共に土地の肥沃度は滅少し， 山地の人口は減少しはじぬた。

現在の森林の樹令は古いものでも 60 年生程度である ことから考えても，20世紀はじめに一度皆伐され牧場

* 京都大学農学部, ** 京都芸術短大

†南北戦争から 1900 年まででも年間 $2,500 \sim 3,000$ 万 ボートフィートの木材が伐出されたという。
・農地化した土地に 2 次林として成立したものと思われ る。

はげしい人為的干渉によって荒廃した状況にあったこ の山地が国立公園に指定され，parkway が建設される ことになったいきさつには当時の社会経済的条件を見逃 すことができないだろう。

1920 年代の大不況の対応策として F. D. Roosevelt 大 統領によるニューディール政策が開始されている。その 中ではいわゆる TVA プロジェクトが有名であるが, 南 アパシシアン地帯での景気刺戟, 雇用拡大を大きい目的 として Shenandoah 国立公園（1926 年指定，ただしそ れ以前は州立の公園であったようである。）Blue Ridge parkway（1936 年施工決定）の設立があったようであ る。Shenandoah の Sky Drive は 1939 年に完成し, Blue Ridge parkway は延々工事は継続され（もちろん 中断があったであるう) 現在も施工中の個所がある。

当時この山地の生産力の低下した農地・牧草地を国有 地として買入れることは農民の負担を軽減するに有効で あったし，きわめて低い収入で暮す人々（アパラシアン 山地の住民の農地からの現金所得水準はきわめて低く, 1928 年には年間平均 86 ドルにすぎなかったという記述 がある）に道路工事による現金収入の道を与えることは 極めて重要であった。かつその工事が住民の居住地近く であって出稼ぎの必要がないことも重要な要因であっ た。

もちろん,このプロジェクトに巨額の国費(Blue Ridge parkway の完成のためのコストは1962 年の見積りでも 9,600 万ドルとされ，これは全納税者が 25 年間年間 2 七 ントずつ支払う額であるという記述がある）を投大する ことが簡単に決ったわけではなくて, 計画の構想が1933 年に決ってから議会を通過（1936 年, 賛成 145 , 反対 131 , 育権 147 というわずかな差であった）するまで, North Carolina 州と Tennessee 州との間のはげしい路線選定 競争（結局 North Carolina 州の勝利に終る）をも含め てのはげしい議論の末, 可決されたのである。

ここで強調したいのは，この国立公園あるいは park- 
小橋・森本：海外の法面緑化状況について (II)

way の設立時にこの地域に保護すべき貴重な天然原生 林，あるいはすぐれた自然風景が先に存在していたので はなくて，きわめて荒廃した山地莸国有地化し，森林を 保護育成し（それほど大きい人為的育成手段老講じなく ても2 次林が旺盛に生長しうるという良好な自然条件に めぐまれていたという幸運はあるにしても）国立公園と してはずかしくない景観を作り上げていったというこ と，それをリクレーション資源として最大限に利用古る ために巨額の国費老投じ，理想的 Parkway を作り上げ たということである。

この巨額の出費は年間 1,500 万人を越える钼光客が来 訪する現状を久るとき十分補って余りあるものであり， プロジェクトとして大成功というべきだろう。

Blue Ridge Parkway は全長 470 mile で 現在 77,862 acreの土地を有している。用地は道路沿いに平均 1,000 フィートであり，最低 200 フィートを確保するよう計画 された。

この park way では国立公園として用地化する(Right - of-way）土地ときびしい制限のもとで從来からの豊地・ 牧草地としての使用定認める土地 (Scenic easement) と がある。Scenic easementの土地では音工業用の建物, 電柱，広告等，景観上問題になるものは当然一切認好 ず，樹木類の伐採除去にもきびしい制限があり，景観上 望ましい農耕地，牧場の経営のみ花認めるものである。 この土地は一度国が買い上げて貸付ける方法が多いよう である。

今後この park way の完成までには Right-of-way 及 び easement の形で買入れるべき面積として 8,638 acre 必要という。

1982 年の予算ではこの park way では 269 人・年の 管理要員（Full-Time 176，季節労働 93）が認められ ている。同年の管理費は約 7,300 千ドルで別に工事費 (Grang father Mtn. の新線建設費) 3,400 千ドルがあ る。管理費のうち 3,000 千ドルは通常の維持費であり, 安全対策・資源保護費として 1,000 千ドルを見込えで いる。

観光客の安全対策で問題になっているのは，第一に交 通事故であり, 1981 年中に 13 人が死亡, 195 人の真傷者, 525 千ドル以上の損害を出している。その原因のほとえ どはスピードオーバーと飲酒運転による。次の問題は盗 難等刑事事件であり，レンジャーの报った 1981 年の事 件は約 4,000 件にの姫，1980 年より $17 \%$ も増加して いる。

park way の維持管理で最も力が注がれているのは刈 込作業の合理化，エネルギーの節約である。要するに刈
込回数を減らすことであり，現在は法肩部 48 インチの 㺫込が主体である。1980年に汇35\% 6石油消費量を減 らせたとしている。刏込回数䘮減らすために，以前のき れいに刈込まれた芝生地が多られなくなったといら苦情 (これは特に春にオープンした後第1回の㺫込みが行わ れるまでに多いという）もあるが，㺫込しないために今 までは見られなかった野の花が齐られるようになる利点 も出てきたという。㺫込回数を減らすという方向は植生 遷移を許すことであり路傍景観が急速に变化する可能性 があり重大なことである。

山岳道路であるから災害がある。特に岩盤法面で頁岩 地带では落石を主体にしたものがある。春さきの出水, 凍結ゆう解による崩落（これも春に多い）が多いが構造 物による対策工は皆無といってよい。危険な浮石を整理 するのが主な対策で 1982 年の予算で 30 万ドルを見込ん でいる。もちろんそれで十分とは考えていないようで， 予算が許せば防護柵程度は設置したい考えはあるよう だ。災害発生頻度等くわしい事情がわからないから論評 しにくいが，自然災害に対する考え方（特に管理責任の 考え方）がわが国とかなり異なるように思えた。

\section{2 法面及び Road side の管理実態}

park way における周辺景観の取扱いの基本はドシイ バーの視野を庆く開けるように道路両側にかなりの幅で 㺫込を盛えに行う芝生区域を設けること，つまり道路両 側にまず芝生地があって，その奥に樹林帯があることで ある。また比較的道路より近い位置の林はすかし切りを 行なって林内を見えるようにすること，あるいは見晴ら しのよい所でも枝すかしや伐採を行って見通しをよくす ることである。

その結果 park way を走行する車からは広々とした 印象を与える。また余りに車から近い位置にある林はよ

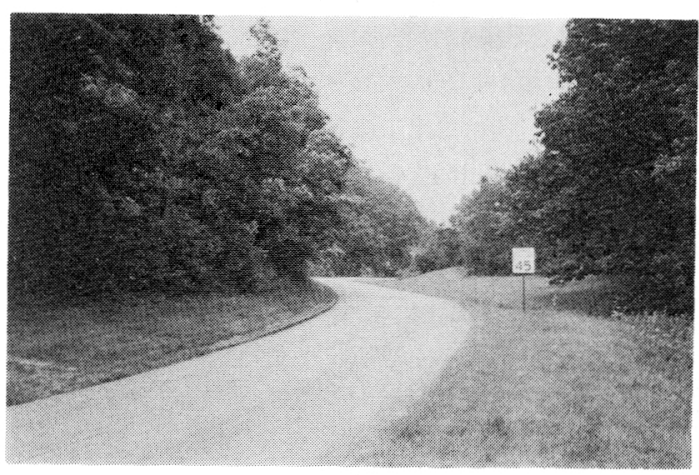

写真-1 Blue Ridge Park Way 道路両側に十分な空 間を持ち，開けた視野を与える 


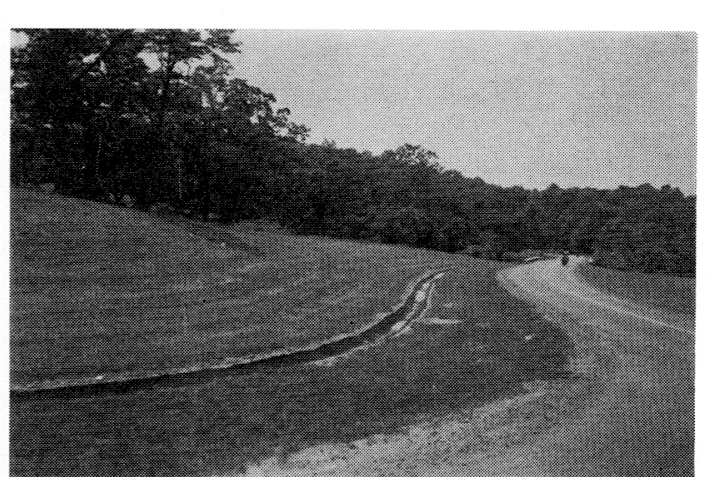

写真-2 (B. R. P. W.) 切取面も㺫込久, 芝生地で維 持するのが基本である

く見えないし，ある距離学置いてよく観察できることも 確かである。

切取, 盛土法面は道路に近接した位置にあり, 上述の 刈込区域，芝生地区域に位置する。それ故，大部分の法 面酒々刈込まれて, 芝生地状況の植生構造が維持され ることになる。もちろん, 㺫込を可能ならしめる公配 （せいぜい 2 割程度までであろう）の限界があり，てれよ り急公配になると樹林又は低木地となる。それでも手刚 で時々刈取るという。

つまり, 道路建設に要した区域, 路傍(路肩)の平地, 法面は管理すべきものとして刈込及, 半永久的に樹木の 侵入を許さ奴という考えのようである。もっと大げさに いえば，“自然”の中に開拓した“人間の作ったもの”の 中に樹木という自然の侵入を許さないという基本的な思 想があるよらにみえる。

わが国の山岳道路の法面の植生状況ができるだけ早く 周辺植生と同じように逗移して法面が周辺にとけ込导こ とを望んでいることと極めて対称的である。わが国では 法面という“人間の作ったもの”ができるだけ早く“自 然”の中にとけ込さことを願うわけである。

この地域の法面緑化は 20 年前には Kentucky blue grass（数種類あるという)の移植(張芝)が主体であった が, 最近はこれと Tall fescue (Kentucky 31 fescue) との混播で, Dutch clover 夌混入することもある。施工 法は Hydro-seeding で straw, fiver のマルチ材を用 い, 時には Jut matを用いることもある。

先にのベたように路肩以外の刚込回数を減少している ようであるが, mower が使える所は 4 10 月に 3〜4 回，年 1 回を刈るようである。

建物周辺部の修景的な場所を除き，樹木莸植栽するこ とはない。植栽する場合でも自生しているものの移植で ある。
全体的に夕て, 樹木の生長は旺盛であり, 切取・盛土 法面で刈込学やめると早期に Pioneer 樹種の侵入があ る。

Pioneer として black Cocas と呼えでいるもの《Rhus (ヌルデの類), Rhus glabra. Rhus typhnia) が多く, Robinia (二セアカシア) もあるが 2〜3 年で 5〜6 feet になる。2 次林としては Oak 林であり, タライマック スは hackryであるという。

見通しをよくするための除伐には力を入れており， Sky Driveでは年間 500 本も伐採する。要するに生長抑 制コントロールに苦心しており施肥の必要性はないよう である。

岩盤法面は放置されるが在来植生の侵入がかなりあ り，花木類や法面の目暚しになるものはていねいに残し ており，見苦しい法面は少ない。

全体に長大法面が少なく, 道路を遠方からみた景観(外 部景観）で問題になる所は少ない。これは樹木の生長が よいためもある。

長大法面が少ないのは基本的には地形が比較的なだら

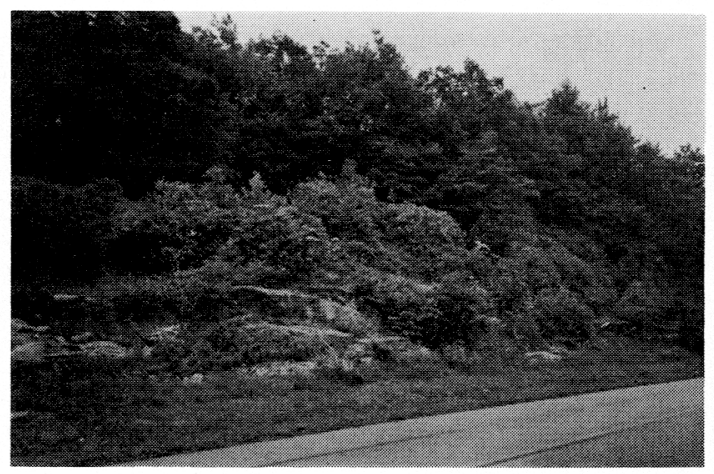

写真 -3 (B. R. P. W.) 岩盤の処理, 花木類 (在来種) 走生かしてる

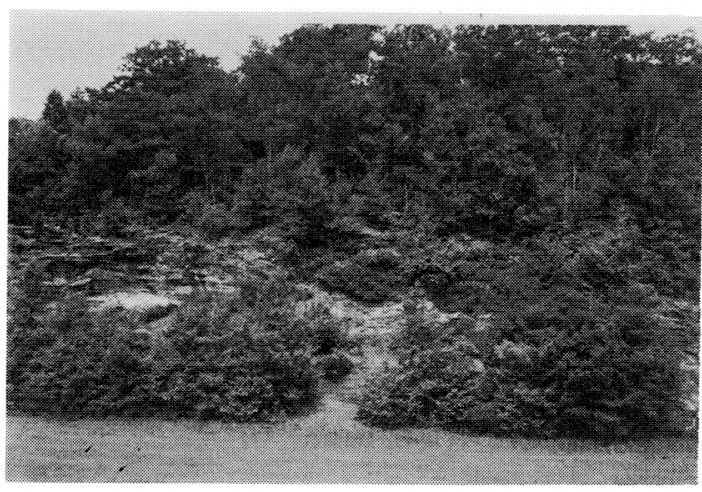

写真-4 (B. R. P. W.) 岩艋斜面，侵入した針葉樹を 育成し，目かくしとしている 


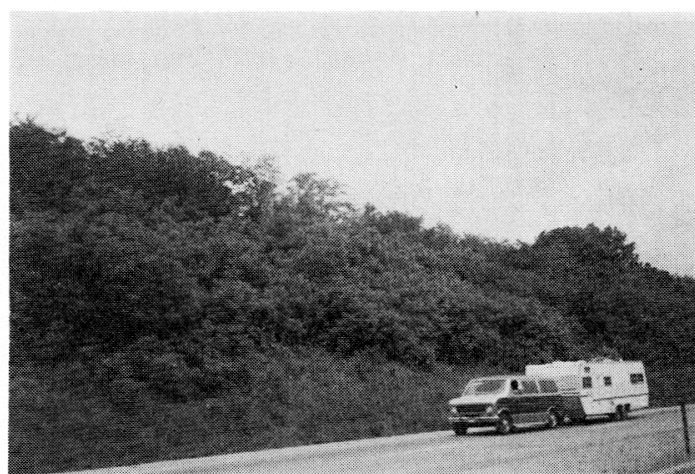

写真-5 (B. R. P. W.) 切取法面の植生遷移 Rhus 類 が盛えに侵入している

かであり，路線ルートに山頂近くの緩勾配地をえら艺れ ていることである。又，施工を 1936 年に開始して以来 法面造成後長年月を経ているものが多く植生回復してい るためもある。

\section{Vail Pass}

\section{1 その計画}

Vail Pass は Interstute Highway 70 (Denver-Vtah 它結ぶ線）の一部で 1973 年に着工され 1978 年に完成 された道路である。その最高海抜高は $3,200 \mathrm{~m}$ に及ぶ, ロッキー山脈の南部を横切る道路である。そのためこの 付近の植物の生長期間は短かく, 自然植生の修復が難し い。かつ地質的にも軟弱で，地すべりや土砂害の問題も 多い。しかし，一方において自然景観としてすぐれてお り，多数の観光客をひきつける場所であり，道路建設時 の景観処理は大きい問題であった。それゆえ，この道路 の建設に当っては USA Department of Highways, Forest Service を中心として広い範囲の専問家よりなる プロジェタト・チームによって細心かつ独創的な景観修

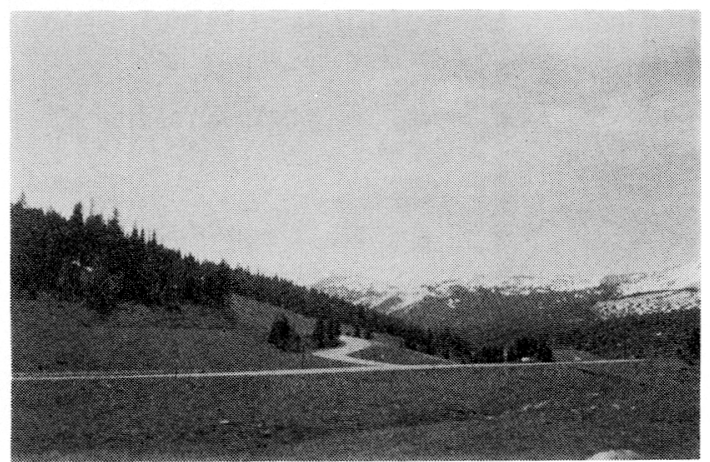

写真-6 Vail Pass 周辺の景観，海抜 $3000 \mathrm{~m}$ 岩越える 寒冷地であり，植物の生育条件は悪い

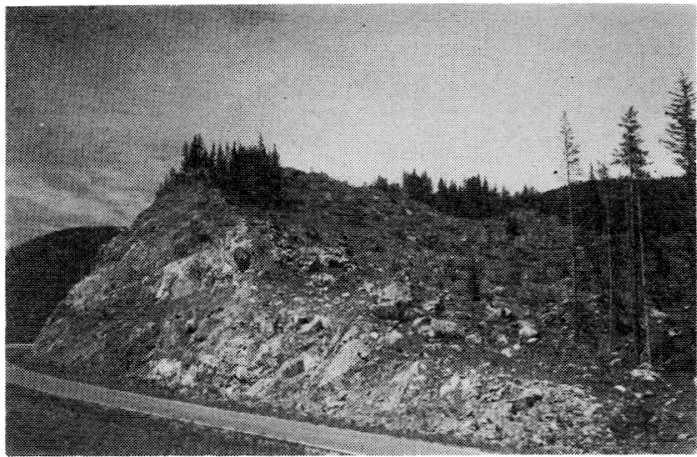

写真-7 (V. P.) 直線的な切取り，景観的に好ましくな

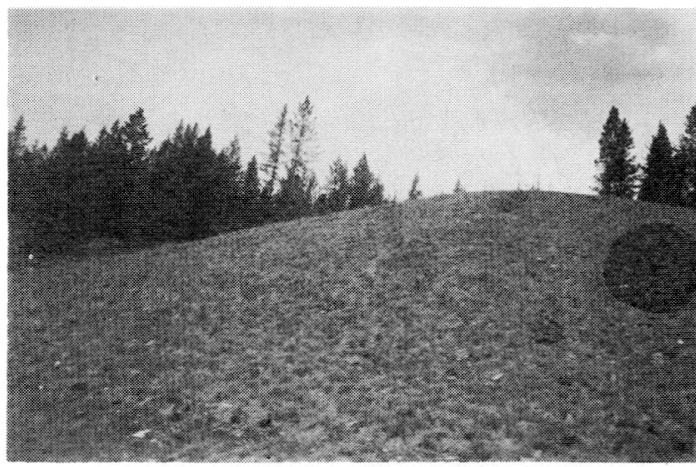

写真 8 (V. P.) ラウンデングと芝草による緑化

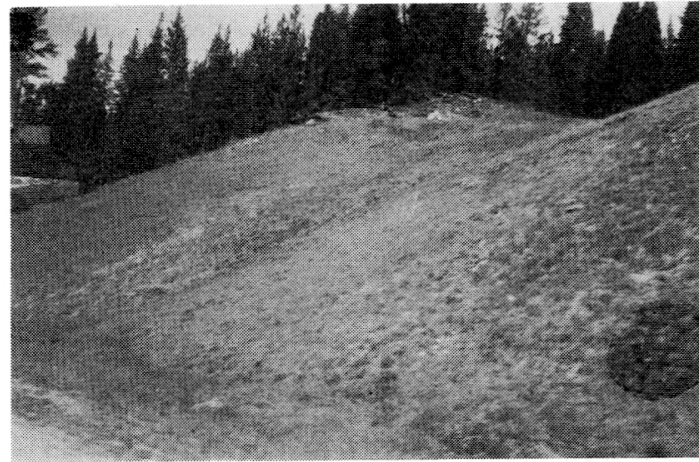

写真-9 (V. P.) 縦方向, 横方向にやわらかい曲線で形 成された切取り法面谷筋に当る所をへこませて いる

復計画が行われた。

この計画の特長は景観対策, 自然植生修復を目的とし た思い切った土工計画にある。

この付近の景観の特性はなだらかで大きい起伏，所々 に多られる切り立った岩盤崖, 厇々とした草生地，針葉 樹林である。 
道路建設による地形改変はこの原景観にマッチするよ う計画された。それは切取法面の造成において顕著に外 られる。從来の直線的，人工的な形の切取をやめ， シウ ンデング（これは法面の縦断面での円久づけ）と谷筋に 当る所をなだらかに阿をせる（法面の横断面での円久づ け）というなだらかな法面を作ることである。

もう一つの特長は岩盤の処理である。これも，人工的 な直線的ながけになることを避け付近の自然景観にみら れる不整形の階段状の人工崖を作ることである。なだら かな斜面でも岩盤のある所では所々に不整形の川所を作 り，岩質を見せ自然にみられる多様性を見せる。

道路建設に伴って水路のつけかえが必要であった。つ けかえ水路はほとえど人工的につけかえたと思え收位に 自然風に作られる。それは自然景観にマッチさせるとい う意畄にもとずくのは当然であるが，この地域はWild life の場, 特に Fishing の場として重要な役割を果し ているからである。

斜面の緑化は牧草種子の吹付工を主体としている。寒 冷な所であるのでその種子選択は難しい問題であるが,

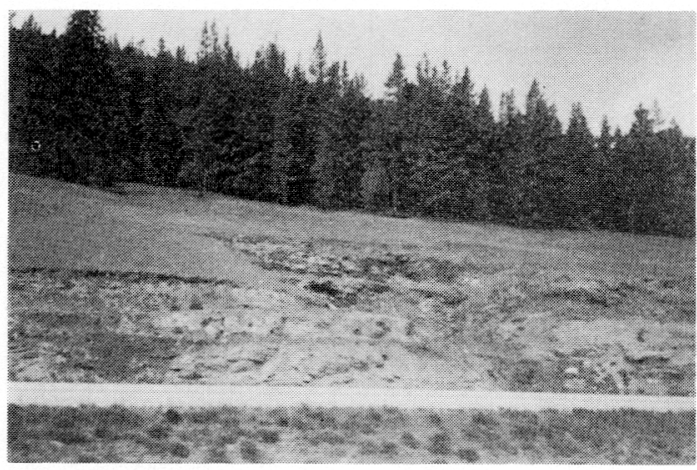

写真-10 (V. P.) 意識的に不整形に仕上げた岩壁面

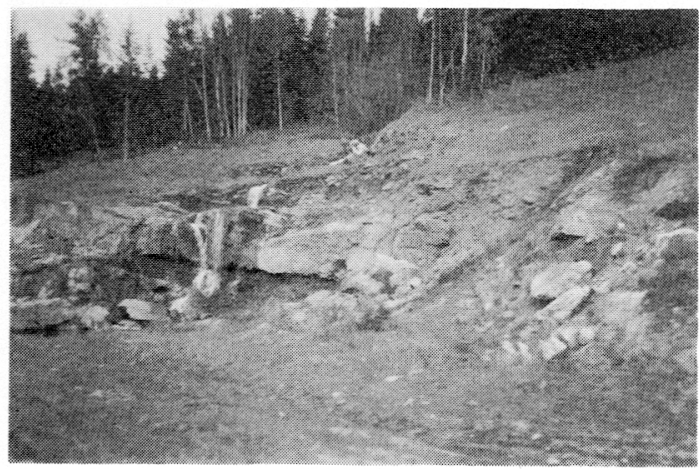

写真 -11 (V. P.) 同上，流水も自然の滝のように仕上 げている
海抜高別に慎重に選ばれている(いずれも数種の混合で ある)。また部分的には在来種, 野草（花の媄くもの）も

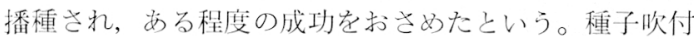
の上から，Jute mat がしきつめ養生する方法が主に行 われる。

また，道路周辺から採取した山引苗木（マッ類，かな りの大苗もある）を植栽する。

斜面の所々にはアクセントをつける目的で大石を置く (まとめて山のように積上げている例もある)。

構造物はできるだけ避けているが，部分的には土留よ うへきが必要な個所がある。ここでは補強土工法（プレ キャストWall 老鉄の Tie で引热, 盛土で固定し，支持 する。Tieback Wall)を多用している。これは表面に出 るWall 板もうすいものですみ目立たない。Wall 板も円 㧩状の曲板にしたものが多く，色彩も考虑してある。高 い斜面ではこの Wall を階段状に設け，段上には植栽し ている。一部には喍のワクようへきも用いている。

急斜面では橋りょう方式にして切取を防いでいる。橋

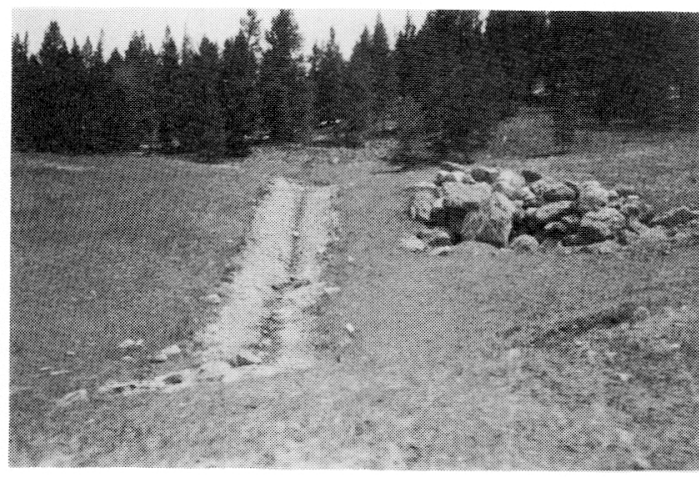

写真-12 (V. P.) 蛇かご水路とアクセントをつけるた め㯰いた石群

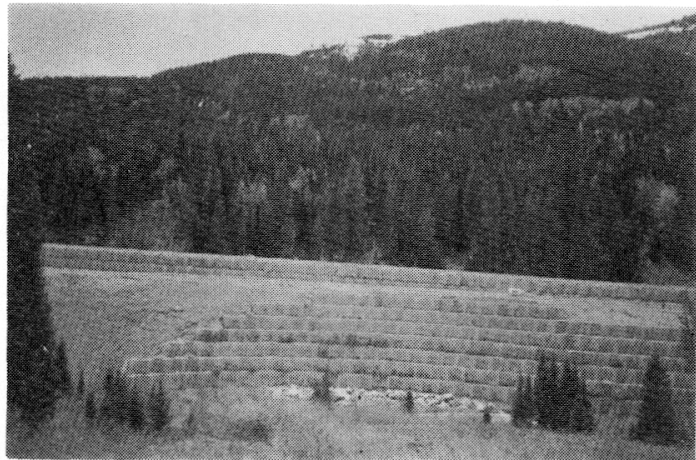

写真-13 (V. P.) ようへきも景観的配虑をしている 半円形のコンクリートパネルによる補強大工 法。薄いパネルですむので圧迫がない 


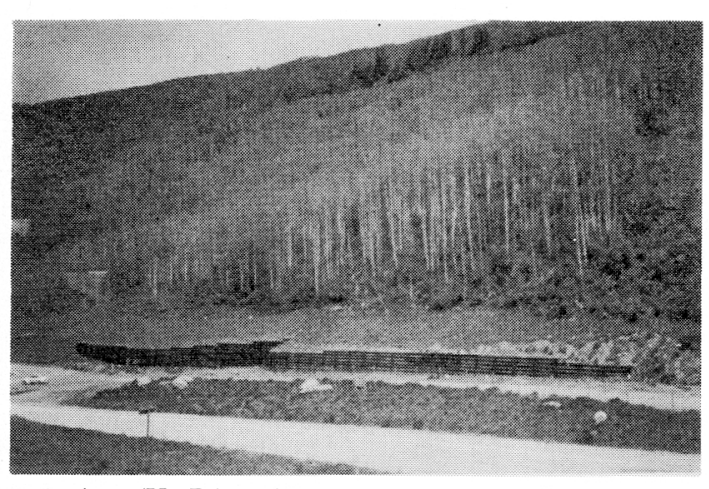

写真-14 (V. P.) 景観とマッチするよう考えられた木 製ワクようへき

りょうを多用しているが，それらはプレキャストのセグ メントを組立てる方式でスレンダーなものを用い, 周辺 景観の中で目立た妨うにしている。

もう一つ大きい問題は工事中の公害対策である。乙れ は特に土工事によって生じる泥水処理に注意が払われ た。この地域は Wild life の場として重要であり, 工事 中の泥水が，河川に流入することをいかに防ぐかが大き い問題であった。そのため工事区域の集水域の水はす心゙ て調整池（自然の池を用いる時もあるが，一時的な簡単 な調整池を用いる時もある）に貯留し，泥を沈澱させ清 水のみを排出するようにした。工事時は常に監視し，思 わ奴所から泥水が排出されるときは急に小さい池を作 り対応する。簡単なワタたばを積上げたダム(Hay check dam）はフィルター効果があることから応急的によく使 われた。

\section{2 その実態}

以上の計画は主として文献にもとづいて知りえたこと である。ここでは現地を見た感想や，同行してもらった 現地の方々の意見を主体にのべる。

われわれは出発前から，この思い切った計画が実行さ れていることは文献で知っていた。最もよくわからなか った点はこの Vail passという道路でなにゆえにぼう大 な経費をかけて景観計画がなされたかという点であっ た。

この問題の答は簡単なことであり, Vail pass はデン バーとVail の町を結ぶ道路で, Vail の町は17 年前に 建設された高級保養地であるということである。この町 は軽井沢より数段高級のリゾートの町であり, 高級な店 や別荘群が立ちならび，近くにはスキー場が数多く開設 されている。またこの町を中心として付近一带はハイキ ング等の野外リクレーションとして重要な場である。そ
れとデンバーを結ぶ道路に最大限の景観的配虑を行な い，かなりの経費を投入しても不自然なことではない。

さて法面の緑化であるが，できるだけ法勾配を $1: 3$ 以下とし, Top soil を6 インチ置き, 種子を播種したの ち, Hay 又は Straw のマルチングを行ない，侵食が盛 えな所はその上からマット（Jute mat）で抑える（金釗 で固定）という力法である。といってもすべて 1:3の 勾配にできるわけではなく, もっと急勾配の所もある。 芝草を主体とした被膜はおお先称成功している。

$3,000 \mathrm{~m}$ をこえる所では $\mathrm{pH}$ が 3 程度の強酸性地であ り， 1 年の生長期間が 45 日しかないとのことで緑化に はかなり苦労している。種子配合等の例を表-1 に示す。 これはかなり高海抜高の所の例である。樹木の植栽も大 面積に行なっているが生長は良くない。上述の悪条件で 植栽可能な樹種がないと歎いていた。芝草種の配合を灰 ても非常に種類数が多い。その理由については明確な解 答は得られなかった。播種あとのマルチング，ネット等 による被覆工はかなり綿密でこれは当然，寒冷地である ためである。

法面のなだらかな曲線はたしかに景観的にすぐれてい る。周囲の景観が大作りであるだけよい効果を上げてい る。しかしそれによって法面積が広くなり，森林の伐採 面積がかなり増えることも明らかであるが，それについ ては全く父にしていないようである。伐採後の森林回復 がきびしい環境条件でかなり困難であるにもかかわらず である。それよりも, 道路に近い森林は伐採し, 広々と した景観の中で，新しい曲線的な法面を生かしていくと いう考えのようである。

岩盤の不整形処理は自然に形成されたがけと区別がつ きにくいほどうまく行わ机ている。発破で仕上げていっ たとのことであるが，精密にデザインに合わせていくの ではなく，かなり大ざっぱに仕上げるようである。

構造物のうち, よう壁は補強土工法を主用している が，この方法だとコンクリート部材の容積は少なくてす み，景観的には非常にすぐれていることは確かである。 これを重力式よう壁にすれば，大変なコンクリートの固 まりになることは確かであろう。強度上の問題があろう がわが国でももっと積極的に利用してはどうであろう か。

全体的にいえば，あり余る広い空間を自由に使い，思 い切った景観デザイン,(そ札は新しい景観を広大な周辺 景観にマッチさせるということである）を行なったとい える。 
1) GRASS SEEDING

表-1 Vail Pass 芝草等配合例

\begin{tabular}{lllcc}
\hline \multicolumn{1}{c}{ Common Name } & Botanical Name & Purity & Germination & $\begin{array}{c}\text { Pounds } \\
\text { PLS/Acre }\end{array}$ \\
\hline Slender Wheatgrass & Agropyron pauciflorum & $90(\%)$ & $85(\%)$ & 2 \\
Meadow Foxtail & Alopecurus pratensis & 95 & 80 & 8 \\
Timothy & Phleum pratense & 99 & 90 & 4 \\
Pubescent Wheatgrass & Agropyron pubescens & 90 & 85 & 4 \\
Smooth Brome (Manchar) & Bromus inermis & 85 & 80 & 10 \\
Ladak Alfalfa & Medicago sativa & 85 & 90 & 10 \\
Kentucky Bluegrass & Poa pratensis & Total PLS/Acre Seeding & 2 \\
\hline
\end{tabular}

\section{2) FORB SEEDING}

\begin{tabular}{llc}
\hline \multicolumn{1}{c}{ Common Name } & \multicolumn{1}{c}{ Botanical Name } & $\begin{array}{c}\text { Ounces } \\
\text { PLS/Acre }\end{array}$ \\
\hline Primrose, Yellow Evening & Oenothera hookeri & $1 / 2$ \\
Penstemon & Penstemon spp. Mixed & $1 / 2$ \\
Gentian, Fringed & Gentianopsis thermalis & $1 / 4$ \\
Iris, Wild Blue & Iris missouriensts & $1 / 2$ \\
Flax, Wild Blue & Linum lewisii & $1 / 2$ \\
Columbine & Aquilegia & $1 / 4$ \\
Daisy, Aspen, Fleabane & Erigeron speciosus & $1 / 4$ \\
Composites & \multicolumn{1}{c}{ Total PLS/Acre Forbs } \\
\hline
\end{tabular}

3) FERTILIZER \& MULCH

$\begin{array}{lr}\text { Nitrogen (Available) } & 50 \mathrm{Lbs} / \text { Acre } \\ \text { Super Phosphate } & 100 \mathrm{Lbs} / \text { Acre } \\ \text { Mulching (Hay or Straw) } & 2 \text { Tons/Acre }\end{array}$

\section{3. ロスアンジェルス周辺}

ロスアンジェルスは温暖な気温の地域にあるが，特に 植物生育期に降水量が少ないため法面を放置しておくと 植生回復は進まない。しかし灌水さえしてやれば耐寒性 に欠ける植物でも生育可能で世界各地から園芸植物が導 入されている。法面でも例外でなく，多様な植生構成の 法面がみられる。

フリーウェイの法面をみると，その地被植物としては へデラ類と Ice plant 類が多く目についた。へデラ類で はカナリェンシス (Hedra canariensis) と一リックス (H. helix) の基本種が多い。Ice plant とはザクロソウ 科の多様な植物の 総称であるが，いずれも耐早性に富
み，美しいさまざまな色の花がみられ，しかもほとんど 管理を要しない。ほふく性のものから低朴状になるもの まである。フリーウェイの法面にはこうした地被植物と 共に低木, 高木も植栽されており, 特に道路の立体交差 点付近の盛土法面によくみられる。

キョウチクトウ類, ワシントニア, ユーカリ類, アカ シア類がよくみられる。

フリーウェイの広大な法面が植物生長期に灌水なしに は維持できず, 朝夕 2 回散水を続ける努力は大变と思う が，口ス周辺の緑はすべて灌水で維持されているわけで あたりまえのことなのである。しかし，近年，水の值段 が高くなり，節水が非常に大きい問題として考えられて いる。口ス周辺で多様な地被植物の研究が多いのは第一 


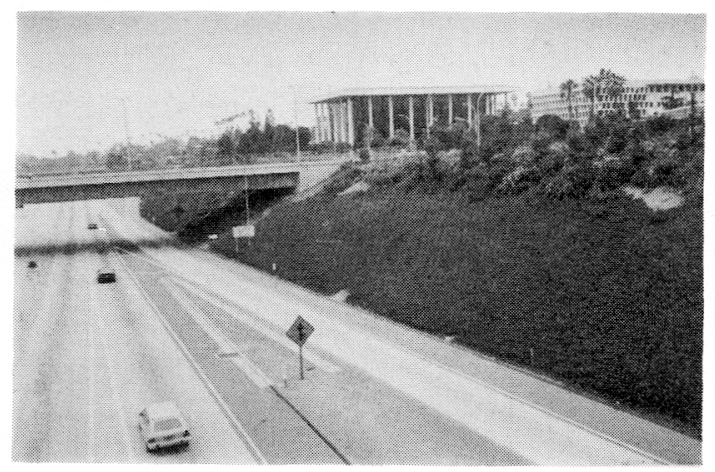

写真-15 ロスフリーウェイ, 切取法面での Ice Plant

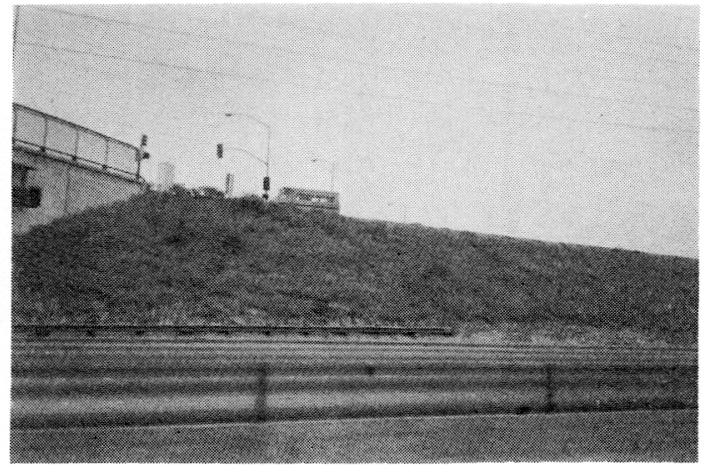

写真-16 ロスフリーウエイ斜面の植生も散水管理がな いと維持できない

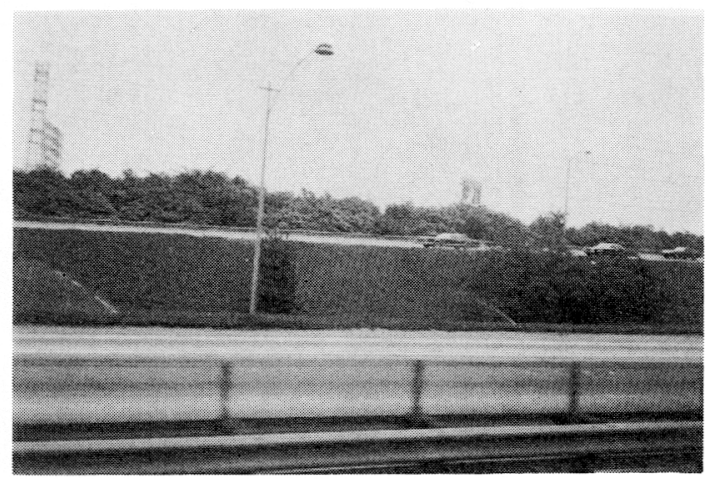

写真-17 ロスフリーウェイ, 法面への散水状況

に水が少なくてすむ植物をみつけるためであり，多量の 水を要する芝草類から，節水型のへデラや Ice plant に 転換してきたといえよう。

ロス中心部から南東約 $50 \mathrm{~km}$ のオレンジ郡の丘陵地 帯の Anheim Hills に最近造成された住宅団地がある。 この団地の特長は 3 つあり, 一つは土地造成法でもとの 地山の形をいかしてなめらかな曲線的な形 (Vail passの 小型版のような考え方であるが）に仕上げたことと，法 面の灌水法，それととこに用いる植物種である。

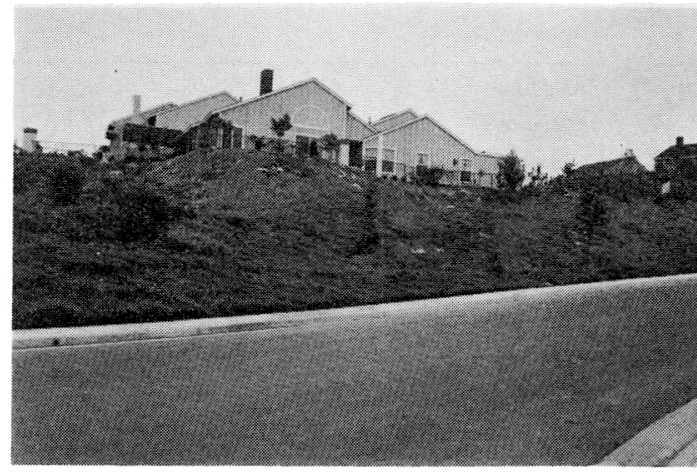

写真-18 口又周辺, 住宅団地曲線的な土地造成と郷土 植物の利用

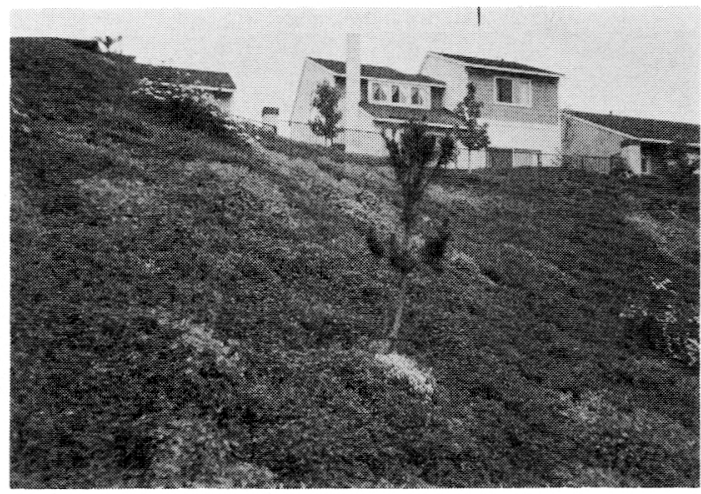

写真-19 口ス周辺住宅団地さまざまな郷土植物の群生 した法面

造成法については，四角ばったいかにも人工的な法面 はなく，曲線が用いられ，小さい単位の住宅群のレベル を変え，向きをかえて造成されている。法面は水平方向 にカーブしているが，そのツ部は奥深く，自然の谷のよ うな個所もある。

法面の灌水法は高水压のスプリンクラー散水は効率が 覀いので，ここでは等高線に沿って細いパイ゚が高密度 に設置され，低水压のドリップ灌水が行われている。こ の方が水の効率がよく, 破損しにくく,メンテナンスが容 易という。ただし当初の設置投資は多く要するだろう。

植物材料はできるだけ水を必要としない植物が検討さ れ，耐旱性の強い鄉土植物が利用されていた。その種は 表-2 の通りであるが，その選定に当っては (1) 自生のも の, (2) 耐早性が少ないもの, (3)法面火贸を避けるため油 分の少ないもの, が考えられた。

播種後 2 年ほどは灌水するが，そのあとはしなくてす むようにしたいという考えであった。

デザイン的な見地から，マッ，ユーカリ類の樹木も導 入され，法面の川地には濃緑色，凸部は明るい色になる 
表-2 アナハイム・ヒルズの法面に播種された植物 りス卜

\begin{tabular}{ll}
\hline Ribes aurem & Cistus villosus \\
$R$. sanquinium & Salvia mellifera \\
$R$. speciosum & Lotus scoparius \\
$\begin{array}{l}\text { Dendremecon rigida } \\
\text { Eschscholtzia }\end{array}$ & Viguieria lacineata \\
californica & Yucca whipplei \\
Eriophyllum & \\
confertiflorum & Artemisia pycncephala \\
Encelis falinosa & Lupinus sp. \\
Baccharus pilularius & \\
\hline
\end{tabular}

よう，樹木は凹部に凸部は地被植物のみとするようにし ている。

かなり思いきった住宅団地の造成法であり大変興味深 かったが，さまざまな色彩の花が吹く雑草群とユーカリ などなじみの少ない植生構成の景観は筆者にとっては異 様な感じであった。

\section{4. まと め}

旅行中にみた各地の法面の植物種（芝草）を日本植生 (株)の谷口美津男氏が調べられているので表-3 に示す。

さて，アメリカ旅行で感じたことをまとめると以下の 通りである。

1）斜面緑化工法として特に目新しいことはなかっ た。またわが国で行われているような大規模な土木工作 物の法面工（コンクリート吹付工，格子ワク工など）は 全くといってもよいほど見られず，よう壁工すらまれで あった。
2）それは基本的には国土の広さの差であろう。道路 法面でも切取面と道路との間にかなり広い空間があり， わが国のように小落石で大事故を生じるというような確 率は少なくなる。災害に対する考方方にかなり差がある ようである。山体の切盛りする際の自由度が大きいか ら，緑化しやすいように法面造成の方を考学る（緩勾亚 化，垂直・水平方向のラウンデングなど）方向へ進仝， 緑化施工法について苦心する比率が少ないように久光 た。わが国のようにかざられた悪い条件の法面でなんと か緑化しようと施工法に工夫をこらすというのと逆の方 向である。

3）緑の見方というか自然観というかその違い。わが 国では人間が作ったもの（道路とか）をなるべく早くも との景観の中に入れてとけ込まそうとするが，米国では 人間が作ったものを新しい景観として維持しようとする （それは人工的景観という意味でなく，周辺景観とのバ ランスは考えるが，もとの景観にとり込ませようとは考 えない)。それではじめて景観デザインといえるのかも知 れない。

4）Vail pass にみられるような思いきった発想， そ の実現のために参加した各方面の専門家，特に土木技術 者の積極的な参加は（わが国ではともすれば土木技術者 を環境破壊に押込めようとしかしない）まことにうらや ましい。

わが国では“緑を守る”とか“環境保全”の考え方が 余りに一様化しすぎている（というょり，ほかの考え方 を認めようとしない)。もっと柔軟な多様な考え方を認好 議論できるようにすることがまず必要と思う。

\begin{tabular}{|c|c|}
\hline 場 & 主な草地, 生育状況 \\
\hline ピッツバークからホイーリングまで（道路法面） & トールフェスク，クラウンベッチが多くみられた。 \\
\hline $\begin{array}{l}\text { ホイーリングからワシントンまで（道路切取, 盛土法 } \\
\text { 面) }\end{array}$ & 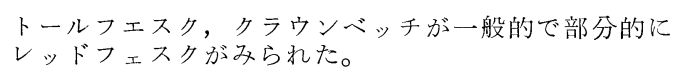 \\
\hline ワシントン道路法面 & $\begin{array}{l}\text { トールフェスク，ケンタッキーブルーグラスがみられ } \\
\text { た。 }\end{array}$ \\
\hline ワシントンからシェナンドーアまで（道路法面） & トールフェスクが主体 \\
\hline \multicolumn{2}{|l|}{ ブルーリッジパークウェイ } \\
\hline 道路法面 & $\begin{array}{l}\text { トールフェスク，レットフェスク，スムースブロムグ } \\
\text { ラス }\end{array}$ \\
\hline パーキングエリア & ケンタッキーブルーグラス \\
\hline アッシェビルからフランクリン（道路切取法面） & $\begin{array}{l}\text { 主としてトールフェスク, 中にメドハギ混在も多くあ } \\
\text { る。スイカズラ, クズが全面被覆している所もある。 }\end{array}$ \\
\hline グレートスモーキー道路法面 & トールフェスク，レッドフェスク \\
\hline ベールパス付近道路法面 & $\begin{array}{l}\text { チモシーが主で，ケンタッキーブルーグラス，ホイー } \\
\text { トグラス }\end{array}$ \\
\hline ロスアンゼルスフリーウェイ法面 & ヘデラ, アイスプラント \\
\hline
\end{tabular}

